\title{
XIST and RPS4Y1 long non-coding RNA transcriptome as sex biomarkers in different body fluids
}

\author{
Fatma Mohamed Hassan ${ }^{1 *} \mathbb{D}$, Heba Abdo Abdel Razik', Miriam Safwat Wadie ${ }^{2}$ and Dina Sabry Abdelfattah²
}

\begin{abstract}
Background and objectives: Sex determination of an individual based on biological fluid evidence is a critical issue in forensic science. RNA has proved valuable in the identification of body fluids and the estimation of stain age. However, it still could not provide sufficient information about their donor. This study aimed to evaluate the potential use of the long non-coding XIST and RPS4Y1 markers in the identification of sex from different body fluids.
\end{abstract}

Methods: Saliva, semen, and peripheral and menstrual blood samples were obtained from apparently healthy volunteers. The expression of XIST and RPS4Y1 was assessed in these samples using real-time RT-PCR.

Results: XIST was detected in female saliva and peripheral and menstrual blood, while RPS4Y1 was detected in male blood and semen.

Conclusion: XIST and RPS4Y1 could be sex differentiation biomarkers in various body fluids.

Keywords: Sex identification, Body fluids, Long non-coding ribonucleic acid, X-inactive specific transcript, Ribosomal protein S4, Y-linked 1

\section{Background}

Accurate sex identification from biological samples is a vital issue in forensic casework (Borovko et al. 2015). The most commonly used method for human sex determination is based on the sex-typing marker amelogenin (Butler and $\mathrm{Li}$ 2014). The amelogenin gene is a single-copy gene, located on the $\mathrm{X}$ (AMELX) and $\mathrm{Y}$ (AMELY) chromosomes at Xp22.1-Xp22.3 and Yp11.2, respectively (Nakahori et al. (1991a); Nakahori et al. (1991b); Sasaki and Shimokawa 1995). In sex identification procedures, this gene is amplified for detection of the $\mathrm{X}$ and $\mathrm{Y}$ alleles. The presence of two amplified products indicates a male genotype, while a single amplicon indicates a female genotype (Giuliodori et al. 2011). Several studies have shown that the amelogenin is not a reliable tool for sex determination (Nakahori et al. (1991a); Nakahori et al. (1991b); Sasaki and Shimokawa 1995;

\footnotetext{
*Correspondence: fatmahasan.2010@yahoo.com

${ }^{1}$ Forensic Medicine and Clinical Toxicology, Faculty of Medicine, Cairo

University, Kasr Alainy Street, Cairo 11562, Egypt

Full list of author information is available at the end of the article
}

Giuliodori et al. 2011; Maciejewska and Pawłowski 2009; Turrina et al. 2010). Mutations of AMELY may cause the failure of its amplification in male biological samples and their misidentification as female samples. Non-AMELY alleles' cases have been detected worldwide in different populations and with different percentages. Therefore, an additional reliable method is needed to accurately identify the sex of a sample donor (Borovko et al. 2015; Nakahori et al. (1991a); Nakahori et al. (1991b); Sasaki and Shimokawa 1995; Giuliodori et al. 2011; Maciejewska and Pawłowski 2009; Turrina et al. 2010).

The analysis of RNA has shown valuable results in the identification of body fluids (Roeder and Haas 2016) and the estimation of the age of body fluid stains (Alshehhi et al. 2017; Simard et al. 2012). However, it could not provide evidential data about the sex of the stain donor (van den Berge and Sijen 2017). Many studies searched for the sex differences in neuropsychiatric diseases (Ji et al. 2015), cancer, (Shi et al. 2013; Weakley et al. 2011), and other human disorders (Shi et al. 2013) using sex-specific RNA markers. In forensics, van den Berge 
and Sijen (2017) studied the use of XIST and RPS4Y1 in sex identification from body fluids and organ tissues where they reported promising results.

In this study, we aimed to further evaluate the potential use of these two markers (XIST and RPS4Y1) in sex identification from different body fluids.

$\mathrm{X}$-inactive specific transcript (XIST) is a long non-coding RNA involved in X-chromosome inactivation $(\mathrm{XCI}) . \mathrm{XCI}$ is an essential biological process which is responsible for the inhibition of X-linked genes overexpression in women to maintain the same dosage between males and females ( $\mathrm{Ji}$ et al. 2015). During development, one of the $\mathrm{X}$ chromosomes becomes randomly silenced. This silencing is automatically inherited all through the process of somatic cell division. The chief of this process is the XIST (Staedtler et al. 2013; $\mathrm{Ng}$ et al. 2007).

Ribosomal protein S4, Y-linked 1 (RPS4Y1) is one of the genes found on the $\mathrm{Y}$ chromosome that proved to have the greatest expression difference between both sexes (Vawter et al. 2004; Melé et al. 2015) and is expressed in all male human tissues (Planchard et al. 2009).

\section{Materials and methods Subjects}

Fifty apparently healthy volunteers participated in this study (25 males and 25 females) after providing their informed consent. The male volunteers (aged 20-58 years) provided their saliva, peripheral venous blood, and semen samples. The female volunteers (aged 26-45 years) provided their saliva, peripheral venous blood, and menstrual blood samples. Exclusion criteria included the history of cancer and treatment with chemotherapy as long non-coding RNAs have abnormal gene expression in tumors (Weakley et al. 2011). The Ethical Committee of the Faculty of Medicine, Cairo University, approved this research.

\section{Sample collection}

Peripheral blood was collected in ethylenediaminetetraacetic acid (EDTA) tubes via venipuncture. Saliva was collected from participants who were asked to spit saliva into test tubes after withholding oral hygiene procedures, taking food or drinks, or smoking for an hour before collection. Semen was provided in plastic cups. Menstrual blood was collected from the vagina using sterile cotton swabs which were left to dry at room temperature for $24 \mathrm{~h}$. All samples were stored frozen at $-20^{\circ} \mathrm{C}$ until further processing.

\section{RNA extraction}

Total RNA was extracted using RNeasy Mini Kit (Qiagen) and then was analyzed for both quantity and quality with Beckman dual spectrophotometer (USA).

\section{Reverse transcription and real-time PCR}

We used $10 \mathrm{ng}$ of the total RNA from each sample for cDNA synthesis. The high capacity cDNA Reverse Transcriptase kit (Applied Biosystems, USA) was used for reverse transcription. Then, the cDNA was amplified with the Syber Green I PCR Master Kit (Fermentas) using the Step One instrument (Applied Biosystems, USA) as follows: enzyme activation for $10 \mathrm{~min}$ at $95^{\circ} \mathrm{C}$, then $40 \mathrm{cy}$ cles of $15 \mathrm{~s}$ at $95^{\circ} \mathrm{C}, 20 \mathrm{~s}$ at $55^{\circ} \mathrm{C}$, and $30 \mathrm{~s}$ at $72^{\circ} \mathrm{C}$ for amplification. For each gene, we used $1 \mu \mathrm{M}$ of forward and reverse primers. Primer sequences for target and reference genes are shown in Table 1.

Calculation of relative quantification (relative expression) After the RT-PCR run, the data were expressed in cycle threshold $(\mathrm{Ct})$. The PCR data sheet included $\mathrm{Ct}$ values of the target genes and the housekeeping reference gene $(\beta$-actin). In order to measure the expression of a certain gene, a negative control sample was used. Therefore, the target gene expression was assessed and related to the reference gene as follows:

$$
\Delta \mathrm{Ct} \text { sample }=\mathrm{Ct} \text { assessed gene }-\mathrm{Ct} \text { reference gene }
$$$$
\Delta \Delta \mathrm{Ct}=\Delta \mathrm{Ct} \text { sample }-\mathrm{Ct} \text { control gene }
$$

And finally, the relative expression (RQ) was calculated according to the following equation:

$$
\mathrm{RQ}=2-(\Delta \Delta \mathrm{Ct})
$$

\section{Statistical analysis}

Data were coded and entered using the statistical package SPSS version 25 , then were summarized using mean

Table 1 Primer sequences specific for each gene

\begin{tabular}{lll}
\hline Gene & Primer sequence: 5'-3' & GenBank accession number \\
\hline XIST (long non-coding RNA) & F: ATTTAACTGATCCCATTGAAGATACCACGC & NR_001564.2 \\
RPS4Y1 ribosomal protein S4, Y-linked 1 & R: TCAGAATGTCCAAGAGGAGCCTAAGG & NM_001008.3 \\
B-actin & F: TGGAAGAGGCAAAGTACAAGTTGTGC & \\
& R: GGATCCCTTCACTCCCACAGTAAT & NM_001101.3 \\
\hline
\end{tabular}


Table 2 Expression of XIST and RPS4Y1 in the studied body fluids of male and female participants

\begin{tabular}{|c|c|c|c|c|}
\hline \multirow{2}{*}{$\begin{array}{l}\text { Body fluid } \\
\text { Peripheral blood }\end{array}$} & \multicolumn{2}{|c|}{$\begin{array}{l}\text { Number of } \\
\text { samples }\end{array}$} & \multirow{2}{*}{$\begin{array}{l}\text { Number of XIST- } \\
\text { positive samples } \\
0\end{array}$} & \multirow{2}{*}{$\begin{array}{l}\text { Number of RPS4Y1 } \\
\text { positive samples } \\
25\end{array}$} \\
\hline & Male & 25 & & \\
\hline & Female & 25 & 25 & 0 \\
\hline \multirow[t]{2}{*}{ Saliva } & Male & 25 & 0 & 0 \\
\hline & Female & 25 & 25 & 0 \\
\hline \multirow[t]{2}{*}{ Menstrual blood } & Male & 0 & 0 & 0 \\
\hline & Female & 25 & 25 & 0 \\
\hline \multirow[t]{2}{*}{ Semen } & Male & 25 & 0 & 25 \\
\hline & Female & 0 & 0 & 0 \\
\hline
\end{tabular}

and standard deviation. The non-parametric KruskalWallis and Mann-Whitney tests were used to compare between quantitative variables (Chan 2003a), while the Spearman correlation coefficient was used to correlate between quantitative variables (Chan 2003b). Statistically significant results were considered if $P$ value is less than 0.05 .

\section{Results}

XIST is expressed in all studied female body fluid samples, with no expression in male samples, while RPS4Y1 is expressed in all male blood and semen samples, with no expression in male saliva or female samples (Table 2).

The mean expression values of XIST and RPS4Y1 in the studied body fluids are demonstrated in Table 3 .

Comparison between XIST mean values in female body fluids (peripheral blood, saliva, and menstrual blood) shows a statistically significant difference, with the maximum mean expression value in menstrual blood and the lowermost mean value in saliva (Table 4). Pairwise comparisons between these body fluids show statistically significant differences between the saliva and peripheral blood, saliva and menstrual blood, and peripheral blood and menstrual blood (Table 5).

Comparison between RPS4Y1 mean values in male blood and semen does not show any statistical significance (Table 6).

The Spearman correlation between participants' age and female XIST and between participants' age and male

Table 3 Relative expression (RQ) values of XIST and RPS4Y1 in the studied male and female body fluids

\begin{tabular}{lllll}
\hline Body fluid & & Sex & XIST & RPS4Y1 \\
\hline Peripheral Blood & Mean \pm SD & Male & 0.00 & $1.05 \pm 0.29$ \\
& & Female & $1.57 \pm 0.56$ & 0.00 \\
Saliva & Mean \pm SD & Male & 0.00 & 0.00 \\
& & Female & $0.30 \pm 0.11$ & 0.00 \\
Semen & Mean \pm SD & Male & 0.00 & $1.35 \pm 0.81$ \\
Menstrual blood & Mean \pm SD & Female & $5.64 \pm 2.20$ & 0.00 \\
\hline
\end{tabular}

Table 4 Comparison between XIST mean values in the studied female body fluids

\begin{tabular}{|c|c|c|c|c|c|}
\hline \multirow[t]{2}{*}{ Gene } & & \multicolumn{3}{|l|}{ Body fluids } & \multirow[t]{2}{*}{$P$ value } \\
\hline & & $\begin{array}{l}\text { Peripheral } \\
\text { blood }\end{array}$ & Saliva & $\begin{array}{l}\text { Menstrual } \\
\text { blood }\end{array}$ & \\
\hline XIST & Mean \pm SD & $1.57 \pm 0.56$ & $0.30 \pm 0.11$ & $5.64 \pm 2.20$ & $<0.001^{*}$ \\
\hline
\end{tabular}

\section{Discussion}

Biological evidence has become extremely important in forensic science. Its presence at the crime scene may provide vital information regarding not only the details about the crime, but also the determination of its owner's identity (Zapata et al. 2015).

The XIST and RPS4Y1 markers have shown encouraging results in sex identification from body fluids and organ tissues (van den Berge and Sijen 2017; Guillén et al. 2014). In this study, we evaluated the use of these RNA markers in the sex identification of a trace donor and also the effect of age on these genes expression.

We chose real-time RT-PCR as the quantification technique because it is a sensitive, accurate, and reproducible method for the detection and quantification of mRNA (Lee et al. 2013; Pfaffl 2004).

We selected the blood, saliva, and semen as the targeted body fluids because of their constant presence at the crime scene. These body fluids are vital in the investigation of many crimes related to sexual abuse, assault and battery cases, and homicides (Zapata et al. 2015). We also added menstrual blood to our studied samples as distinguishing between peripheral and menstrual blood is highly challenging. It requires complex molecular procedures and a considerable degree of experience (Holtkötter et al. 2017).

In this study, we found that XIST is expressed in female body fluid samples (peripheral blood, saliva, and menstrual blood), with no expression in male samples (blood, saliva, and semen), while RPS4Y1 is expressed in male blood and semen samples.

A number of studies concerning human peripheral blood reported that XIST is expressed in females and RPS4Y1 in males. During the analysis of gene expression

Table 5 Pairwise comparisons between XIST mean values in the studied female body fluids

\begin{tabular}{ll}
\hline & $P$ value \\
\hline Saliva-peripheral blood & $<0.001^{*}$ \\
Saliva-menstrual blood & $<0.001^{*}$ \\
Peripheral blood-menstrual blood & $<0.001^{*}$ \\
${ }^{*} P$ value is statistically significant &
\end{tabular}

${ }^{*} P$ value is statistically significant 
Table 6 Comparison between RPS4Y1 mean values in male blood and semen

\begin{tabular}{llllc}
\hline Gene & Blood & Semen & P value \\
\hline RPS4Y1 & Mean \pm SD & $1.05 \pm 0.29$ & $1.35 \pm 0.81$ & 1.000 \\
\hline
\end{tabular}

profile using microarray, Guillén et al. (2014) found that RPS4Y1 was one of the highest expressed genes on the $Y$ chromosome, while XIST was the highest expressed gene on the $\mathrm{X}$ chromosome, and they suggested that these genes can be used as sex-specific biomarkers. Moreover, Xu et al. (2011) found that XIST was highly expressed in females and RPS4Y1 was highly expressed in males with almost no RPS4Y1 expression in females or XIST expression in males. Additionally, $\mathrm{Xu}$ et al. (2011) reported that the ratio of XIST to RPS4Y1 was significantly greater in females which might signify important sex-linked biomarkers for future gene expression analysis in blood.

Menstrual blood is composed of blood, vaginal secretions, and the endometrial cells of the uterine wall (Yang et al. 2012). Since XIST is expressed in female peripheral blood, it would be expressed in the menstrual blood as a cumulative effect. Our results are similar to the previously reported results of van den Berge and Sijen (2017) who observed XIST in four studied menstrual secretion samples with no expression of RPS4Y1.

Saliva is formed and secreted into the mouth by the exocrine salivary glands. Humans possess three main sets of these glands (parotid, sublingual, and submandibular) and numerous minor glands. Most of the saliva $(>80 \%)$ is produced by the parotid and submandibular glands (Turner and Sugiya 2002; Cook et al. 1994). Srivastava et al. (2008) studied the gene expression of parotid gland using microarray, and their results demonstrated the much higher expression of XIST in females and the exclusive expression of RPS4Y1 in males. In this study, we did not detect RPS4Y1 in the male saliva. This is in accordance with the van den Berge and Sijen (2017) study in which they observed XIST only in female saliva and did not observe XIST or RPS4Y1 in the single studied male saliva sample.

Table 7 Spearman's correlation between participants' age and female XIST in the studied body fluids

\begin{tabular}{|c|c|c|c|}
\hline & Body fluid & & XIST \\
\hline \multirow[t]{6}{*}{ Age } & Peripheral blood & Correlation coefficient & -0.212 \\
\hline & & $P$ value & 0.310 \\
\hline & Saliva & Correlation coefficient & 0.049 \\
\hline & & $P$ value & 0.815 \\
\hline & Menstrual blood & Correlation coefficient & 0.196 \\
\hline & & $P$ value & 0.347 \\
\hline
\end{tabular}

Table 8 Spearman's correlation between participants' age and male RPS4Y1 in the studied body fluids

\begin{tabular}{llll}
\hline & Body fluid & & RPS4Y1 \\
\hline Age & Blood & Correlation coefficient & 0.101 \\
& & $P$ value & 0.631 \\
& Semen & Correlation coefficient & -0.058 \\
& $P$ value & 0.782 \\
\hline
\end{tabular}

Similar results were reported regarding the positive expression of RPS4Y1 and the negative expression of XIST in semen by van den Berge and Sijen (2017).

Comparisons and pairwise comparisons were made between XIST mean values in the studied female body fluids. These comparisons show statistically significant differences between the saliva and peripheral blood, saliva and menstrual blood, and peripheral and menstrual blood. This can be explained by the facts that gene expression varies extensively among tissues and that some markers are differently expressed between body fluids (Park et al. 2013; Whitehead and Crawford 2005).

In this study, the Spearman correlation between participants' age and female XIST and between participants' age and male RPS4Y1 does not show any statistical significance.

Age has an evident effect on gene expression (Srivastava et al. 2008; Lu et al. 2004). However, studies which examined age influence on gene expression reported that age-biased genes are genes responsible for several biological functions such as blood coagulation, inflammatory response, transcription, cellular metabolic process, signaling pathway, cell death, and apoptosis, which reflect the cellular aging process in the nucleus and cytoplasm (Xu et al. 2011; McLean and Le Couteur 2004). In addition, Jansen et al. (2014) reported that the fold changes between males and females of the identified sex-specific genes in peripheral blood were highly concordant between age ranges suggesting that the identified sex effects are present in all ages.

\section{Conclusions}

Real-time RT-PCR was successfully applied to all donor samples. The observed results suggest that XIST can be used as a female-specific marker in peripheral blood, saliva, and menstrual blood and RPS4Y1 can be used as a male-specific marker in blood and semen. Further studies including other body fluids and dried and mixed samples should be addressed to consider these markers as universal for sex identification from different body fluids.

\section{Abbreviations}

AMELX: Amelogenin X-linked; AMELY: Amelogenin Y-linked; cDNA: Complementary deoxyribonucleic acid; Ct: Cycle threshold; EDTA: Ethylenediaminetetraacetic acid; RNA: Ribonucleic acids; 
RPS4Y1: Ribosomal protein S4, Y-linked 1; RQ: Relative expression; RTPCR: Reverse transcription polymerase chain reaction; $X C l$ : $X$-chromosome inactivation; XIST: X-inactive specific transcript

\section{Acknowledgements}

None.

\section{Funding}

None.

\section{Availability of data and materials}

The datasets supporting the conclusions of this article are included within the article

\section{Authors' contributions}

$\mathrm{FH}$ and $\mathrm{HA}$ are responsible for the interpretation of results and the writing and final revision of the paper. DA and MW are responsible for the experimental work of the research. All authors read and approved the final manuscript.

\section{Ethics approval and consent to participate}

The Ethical Committee of the Faculty of Medicine, Cairo University, approved this research.

\section{Consent for publication}

Not applicable.

\section{Competing interests}

The authors declare that they have no competing interests.

\section{Publisher's Note}

Springer Nature remains neutral with regard to jurisdictional claims in published maps and institutional affiliations.

\section{Author details}

${ }^{1}$ Forensic Medicine and Clinical Toxicology, Faculty of Medicine, Cairo University, Kasr Alainy Street, Cairo 11562, Egypt. ${ }^{2}$ Medical Biochemistry and Molecular Biology Department, Faculty of Medicine, Cairo University, Cairo, Egypt.

\section{Received: 18 September 2018 Accepted: 11 April 2019}

\section{Published online: 25 April 2019}

\section{References}

Alshehhi S, McCallum NA, Haddrill PR (2017) Quantification of RNA degradation of blood-specific markers to indicate the age of bloodstains. Forensic Sci Int Genet Suppl Ser 6:e453-e455.

Borovko S, Shyla A, Korban V, Borovko A (2015) Amelogenin test abnormalities revealed in Belarusian population during forensic DNA analysis. Forensic Sci Int Genet 15:98-104.

Butler E, Li R (2014) Genetic markers for sex identification in forensic DNA analysis. J Forensic Investigation 2(3):1-10.

Chan YH (2003a) Biostatistics 102: quantitative data - parametric \& nonparametric tests. Singap Med J 44(8):391-396.

Chan YH (2003b) Biostatistics 104: correlational analysis. Singap Med J 44(12): 614-619

Cook D, Van Lennep EW, Roberts ML, Young JA (1994) Secretion by the major salivary glands. In: Johnson LR (ed) Physiology of the gastrointestinal tract. Raven Press, New York, pp 1061-1117.

Giuliodori A, Corato S, Ponzano E, Rodriguez D, Caenazzo L (2011) Rapid analysis for confirmation of amelogenin negative males characterized by a Yp11.2 deletion. Forensic Sci Int Genet Suppl Ser 3:e285-e286.

Guillén IA, Fernández JR, Palenzuela DO, Dueñas S, Han J, Zhang Z, Zhang X, Gao Y, Miranda J, Bringas R, Novoa LI (2014) Analysis of gene expression profile for gender in human blood samples. Int J Innov Appl Stud 7(1):329-342.

Holtkötter H, Dias Filho CR, Schwender K, Stadler C, Vennemann M, Pacheco AC, Roca $G$ (2017) Forensic differentiation between peripheral and menstrual blood in cases of alleged sexual assault_-validating an immunochromatographic multiplex assay for simultaneous detection of human hemoglobin and D-dimer. Int J Legal Med https://doi.org/10.1007/ s00414-017-1719-y.
Jansen R, Batista S, Brooks Al, Tischfield JA, Willemsen G, van Grootheest G, Hottenga JJ, Milaneschi Y, Mbarek H, Madar V, Peyrot W, Vink JM, Verweij CL, de Geus EJ, Smit JH, Wright FA, Sullivan PF, Boomsma DI, Penninx BW (2014) Sex differences in the human peripheral blood transcriptome. BMC Genomics 15:33.

Ji B, Higa KK, Kelsoe JR, Zhou X (2015) Over-expression of XIST, the master gene for $\mathrm{X}$ chromosome inactivation, in females with major affective disorders. $\mathrm{E}$ BioMedicine 2:909-918.

Lee SM, Schelcher C, Gashi S, Schreiber S, Thasler RM, Jauch KW, Thasler WE (2013) RNA stability in human liver: comparison of different processing times, temperatures and methods. Mol Biotechnol 53(1):1-8.

Lu T, Pan Y, Kao SY, Li C, Kohane I, Chan J, Yankner BA (2004) Gene regulation and DNA damage in the ageing human brain. Nature. 429:883-891.

Maciejewska A, Pawłowski $R$ (2009) A rare mutation in the primer binding region of the amelogenin X homologue gene. Forensic Sci Int Genet 3:265-267.

McLean AJ, Le Couteur DG (2004) Aging biology and geriatric clinical pharmacology. Pharmacol Rev 56:163-184.

Melé M, Ferreira PG, Reverter F, DeLuca DS, Monlong J, Sammeth M, Young TR, Goldmann JM, Pervouchine DD, Sullivan TJ, Johnson R, Segrè AV, Djebali S, Niarchou A, Consortium GTE, Wright FA, Lappalainen T, Calvo M, Getz G, Dermitzakis ET, Ardlie KG, Guigó R (2015) The human transcriptome across tissues and individuals. Science. 348(6235):660-665.

Nakahori Y, Hamano K, Iwaya M, Nakagome Y (1991a) Sex identification by polymerase chain reaction using X-Y homologous primer. Am J Med Genet 39:472-473.

Nakahori Y, Takenaka O, Nakagome Y (1991b) A human X-Y homologous region encodes "amelogenin". Genomics. 9:264-269.

Ng K, Pullirsch D, Leeb M, Wutz A (2007) Xist and the order of silencing. EMBO Rep 8(1):34-39.

Park JL, Park SM, Kim JH, Lee HC, Lee SH, Woo KM, Kim SY (2013) Forensic body fluid identification by analysis of multiple RNA markers using NanoString technology. Genomics Inform 11(4):277-281.

Pfaffl MW (2004) Quantification strategies in real-time PCR. In: Bustin SA (ed) A-Z of quantitative PCR. International University Line, San Diego, pp 78-112.

Planchard D, Loriot Y, Goubar A, Commo F, Soria JC (2009) Differential expression of biomarkers in men and women. Seminoncol. 36(6):553-565.

Roeder AD, Haas C (2016) Body fluid identification using mRNA profiling Methods Mol Biol 1420:13-31.

Sasaki S, Shimokawa H (1995) The amelogenin gene. Int J Dev Biol 39:127-133.

Shi X, Sun M, Liu H, Yao Y, Song Y (2013) Long non-coding RNAs: a new frontier in the study of human diseases. Cancer Lett 339(2):159-166.

Simard A, DesGroseillers L, Sarafian V (2012) Assessment of RNA stability for age determination of body fluid stains. J Can Soc Forensic Sci 45(4):179-194.

Srivastava A, Wang J, Zhou H, Melvin JE, Wong DT (2008) Age and gender related differences in human parotid gland gene expression. Arch Oral Biol 53(11):1058-1070.

Staedtler F, Hartmann N, Letzkus M, Bongiovanni S, Scherer A, Marc P, Johnson KJ, Schumache MM (2013) Robust and tissue-independent gender-specific transcript biomarkers. Biomarkers. 18(5):436-445.

Turner RJ, Sugiya H (2002) Understanding salivary fluid and protein secretion. Oral Dis 8(1):3-11.

Turrina S, Filippini G, Voglino G, De Leo D (2010) Two additional reports of deletion on the short arm of the Y chromosome. Forensic Sci. Int. Genet. 5 : 242-246.

van den Berge M, Sijen T (2017) A male and female RNA marker to infer sex in forensic analysis. Forensic Sci Int Genet 26:70-76.

Vawter MP, Evans S, Choudary P, Tomita H, Meador-Woodruff J, Molnar M, Li J, Lopez JF, Myers R, Cox D, Watson SJ, Akil H, Jones EG, Bunney WE (2004) Gender-specific gene expression in post-mortem human brain: localization to sex chromosomes. Neuropsychopharmacology. 29(2):373.

Weakley SM, Wang H, Yao O, Chen C (2011) Expression and function of a large non-coding RNA gene XIST in human cancer. World J Surg 35(8):1751-1756.

Whitehead A, Crawford DL (2005) Variation in tissue-specific gene expression among natural populations. Genome Biol 6(2):R13.

Xu Q, Ni S, Wu F, Liu F, Ye X, Mougin B, Meng X, Du X (2011) Investigation of variation in gene expression profiling of human blood by extended principle component analysis. PlosOne. 6(10):e26905

Yang $H$, Zhou B, Prinz M, Siegel D (2012) Proteomic analysis of menstrual blood. Mol Cell Proteomics 11(10):1024-1035.

Zapata F, Gregorio I, García-Ruiz C (2015) Body fluids and spectroscopic techniques in forensics: a perfect match? J Forensic Med 1:101. 